\title{
JANGAN MENCERAIKAN ISTRI YANG BERZINAH: PENAFSIRAN TERHADAP MATIUS 19:9
}

\author{
Pelita Hati Surbakti \\ Sekolah Tinggi Teologi Cipanas \\ Email: pelita.surbakti@sttcipanas.ac.id
}

\begin{abstract}
ABSTRAK. Salah satu dasar pernikahan Kristen adalah Matius 19:4-6, namun demikian Yesus dalam Matius 19:9 justru disimpulkan membenarkan perceraian dengan sebuah persyaratan. Di tengah-tengah terus meningkatnya angka perceraian suami dan istri di Indonesia, mendiskusikan lagi ayat ini tampanya cukup relevan. Frasa "mē epi porneia" (kecuali karena zinah) dalam ayat ini telah menimbulkan perdebatan. Melalui frasa itu, sebagian besar penafsir menilai bahwa Yesus membenarkan suami menceraikan istri yang berzinah, hanya sebagian kecil yang menolaknya. Menolak terjemahan frasa " $m \bar{e}$ epi" sebagai "kecuali karena" merupakan alasan yang umum digunakan untuk menentang pendapat bahwa Yesus membenarkan perceraian. Sayangnya argumentasi semacam ini telah ditolak oleh sebagian besar penafsir karena sintaksis Yunani dinilai tidak mendukungnya. Kali ini saya akan menggunakan tema utama serta hakikat retorika injil Matius ini sebagai bingkai kerja penafsiran untuk menafsirkan teks tersebut. Dengan pendekatan di atas, Yesus dalam Matius 19:9 secara implisit tidak membenarkan seorang suami menceraikan istri yang berzinah.
\end{abstract}

Kata Kunci: Bercerai, berzinah, retorika Injil Matius, bingkai kerja penafsiran.

\begin{abstract}
One of the foundations of Christian marriage is Matthew 19: 4-6, but Jesus in Matthew 19: 9 is concluded to justify divorce with a condition. In the midst of the continuing increase in the number of divorce in Indonesia, discussing this verse again seems quite relevant. The phrase "me epi porneia" (except for adultery) in this verse has caused debate. Through that phrase, most interpreters consider that Jesus justifies a husband divorcing an adulterous wife, only a small percentage rejects it. Rejecting the translation of the phrase "me epi" as "except because" is a reason commonly used to oppose the idea that Jesus justifies divorce. Unfortunately, this kind of argument has been rejected by most interpreters because Greek syntax is seen as not supporting it. This time I will use the main theme and nature of Matthew's gospel rhetoric as the hermeneutical framework for interpreting the text. With the above approach, in Matthew 19: 9 Jesus implicitly did not justify a husband divorcing an adulterous wife.
\end{abstract}

Keywords: Divorce, adultery, Matthew gospel's rethoric, hermeneutical framework.

\section{PENDAHULUAN}

Angka perceraian suami dan istri di Indonesia kian meningkat dari tahun ke tahun. Angka perceraian tahun 2015-2017 secara berturut-turut adalah sebanyak 353.843, 365.654, 374.516 (Hidayat, 18 Juni 2018), dan tahun 2018 sebanyak 419.268 (Saputra, 03 April 2019). Ada banyak alasan orang bercerai, antara lain adalah perzinahan yang dilakukan oleh salah satu pasangan. Berdasarkan data Ditjen Badan Peradilan Agama (Badilag) Mahkamah Agung RI yang dikutip dalam situs web hukumonline.com, alasan perceraian karena perzinahan pada tahun 2017 adalah sebanyak 1.896 kasus (Hidayat, 18 Juni 2018). Karena data ini adalah data dari pengadilan agama, maka ia merupakan data perceraian di kalangan penduduk yang beragama Islam. Bila ditambah dengan penganut agama lain, maka jumlahnya tentu semakin besar. Data perceraian suami dan istri yang beragama Kristen di Indonesia belum ditemukan, namun tidak berarti perceraian suami-istri Kristen tidak ada. Sebagai contoh adalah kasus perceraian (pasangan yang beragama Kristen) di Pengadilan Negeri Balige Kabupaten TobaSamosir dalam kurun waktu 2015-2018. Pada tahun 2017 tingkat perceraian mengalami kenaikan sebesar 47\% (Siburian, 2019, p. 32). Perzinahan merupakan penyebab perceraian nomor 3 yaitu sebanyak 19,35\% (Siburian, 2019, p. 34). 
Dalam pernikahan Kristen, teks Alkitab yang sering diambil sebagai dasar pernikahan adalah Matius 19:4-6 atau Markus 10:6-9. Namun demikian, Yesus dalam Matius 19:9 seolah-olah membenarkan perceraian dengan persyaratan khusus. Dalam ayat tersebut Yesus berkata, "Tetapi Aku berkata kepadamu: Barangsiapa menceraikan isterinya, kecuali karena zinah, lalu kawin dengan perempuan lain, ia berbuat zinah.” Kata zinah dalam bagian ini merupakan terjemahan dari kata porneia. Kata ini muncul 25 kali dalam teks asli Perjanjian Baru (PB), namun dengan terjemahan yang bervariasi. Karena itu diskusi mengenai apakah zinah merupakan terjemahan yang memungkinkan adalah bagian dari diskusi dalam tulisan ini. Frasa "mē epi porneia" (kecuali karena zinah), yang idenya juga muncul dalam Matius 5:32 (parektos logu porneias), telah menimbulkan polemik tersendiri. Yesus dalam Injil Markus tidak memberi peluang sama sekali untuk bercerai, karena itu frasa kecuali karena zinah tidak ditemukan. Hal ini berbeda dengan Yesus dalam Injil Matius (selanjutnya disebut Yesus). Karena itu sebagian besar penafsir menyimpulkan bahwa Yesus membenarkan seorang suami menceraikan istrinya bila istrinya berzinah (Bdk. Gundry, 1982, p. 377; Janzen, 2000, p. 67, 78-79; Ajayi, 2016, p. 10-11). Namun demikian ada juga sebagian kecil penafsir yang justru melihat bahwa Yesus tidak membenarkan perceraian karena alasan perzinahan (Bdk. Barus, 2014, p. 14). Ada juga yang menilai bahwa Yesus mengijinkan perceraian sebagai bentuk akomodasi kejatuhan manusia (Talbert, 2010, p. 233).

Menolak terjemahan frasa $m \bar{e}$ epi sebagai "kecuali karena" merupakan alasan yang umum diusulkan untuk menentang pendapat bahwa Yesus dalam ayat ini membenarkan perceraian. David Janzen menyatakan bahwa model seperti ini mengikuti tafsiran Agustinus yang telah digunakan oleh Bruce Vawter (Vawter, 1954, p. 155-167) dalam tulisannya (Janzen, 2000, p. 67). Bagi Vawter, mè epi porneia seharusnya tidak diterjemahkan sebagai exept for porneia tetapi sebagai setting aside the matter of porneia (Vawter, 1954, p. 163-165). Armand Barus juga menggikuti pola yang hampir sama yaitu dengan menyorot terjemahan $m \bar{e}$ epi yang menurutnya tidak bisa diterjemahkan "kecuali karena" tapi "bukan karena" (Barus, 2014, p. 14). Sayangnya argumentasi semacam ini telah banyak dikesampingkan yang mana juga telah disadari oleh Vawter sendiri. Janzen (2000, p. 67) menyatakan,

Such a position has been almost universally dismissed by scholars simply because the Greek syntax does not support it, a point that Vawter himself later admitted.

Lagi pula, kalau pun kedua usulan terjemahan di atas bisa diterima, tetap saja masih dapat dimaknai bahwa perzinahan bisa menjadi alasan perceraian. Menurut saya, walaupun dengan frasa kecuali karena zinah tersebut, secara implisit Yesus tetap tidak membenarkan suami menceraikan istrinya yang berzinah.

\section{METODE}

Tulisan ini merupakan penelitian kualitatif melalui studi kepustakaan. Namun kali ini saya tidak akan menggunakan perdebatan mengenai frasa $m \bar{e}$ epi sebagaimana yang umumnya digunakan untuk menyimpulkan bahwa dalam teks ini Yesus tidak membenarkan perceraian. Saya akan menggunakan tema utama serta hakikat retorika injil Matius ini sebagai hermeneutical framework (bingkai kerja penafsiran). Pendekatan ini diusulkan karena argumentasi utama yang umumnya digunakan untuk menolak kesimpulan sebagian besar penafsir yang menilai bahwa Yesus dalam Matius 19:9 ini membenarkan suami menceraikan istri yang berzinah telah ditolak secara luas (Bdk. Janzen, 2000, p. 67).

Pendekatan yang disulkan kali ini didasari oleh pandangan bahwa pada sisi tertentu teks-teks Alkitab merupakan sebuah produk retorika (Bdk. Hayes and Holladay, 2011, p. 87-88; Wenham and Walton, 2001, p. 89-90). Dalam tradisi Yunani, retorika merupakan sebuah seni mengelola wacana untuk meyakinkan pihak tertentu. Bentuk produk retorika pun sangat beragam, di antaranya adalah dalam bentuk tulisan. Dengan demikian kitab Injil utamanya bukanlah kumpulan narasi dan diskursus tanpa tujuan. Sejumlah narasi dan diskursus tersebut dire- 
daksi sedemikian rupa untuk meyakinkan pembacanya atas gagasan yang dikemukakan. Karena itu kitab injil adalah teks yang memiliki tujuan (bdk. Hayes and Holladay, 2011, p. 87, 128; Wenham and Walton, 2001, p. 89). Tujuan tersebutlah yang kemudian berkaitan erat dengan tema utama dan hakikat retorika sebuah teks.

Dalam melakukan penafsiran terhadap sebuah teks, tema utama serta hakikat retorika teks tersebutlah yang kemudian dijadikan sebagai bingkai kerja untuk memahami setiap unit teks dalam teks, dalam hal ini adalah kitab Injil. Wright (2006, p. 68) menyatakan ".. a hemenuutical framework for reading the Bible ... functions rather like a map." Dengan penjelasan di atas, maka penafsiran terhadap produk retorika haruslah dalam bingkai tema utama dan hakikat retorika teks. Tema utama dan hakikat retorika tersebutlah yang menjadi bingkai kerja penafsiran. Ia menjadi peta yang akan menuntun penafsir untuk tiba pada tujuan teks tersebut. Lebih jauh lagi, tema utama ini tidak hanya berguna untuk membaca satu kitab, Wright (2006, p. 26) bahkan telah menggunakan pendekatan ini untuk membaca keseluruhan Alkitab dengan misi Allah sebagai bingkai kerja penafsirannya.

Langkah awal dalam menggunakan pendekatan ini adalah dengan menemukan tema utama serta hakikat retorika sebuah teks. Menemukan keduanya tentu saja dengan memanfaatkan beragam teori hermeneutika yang telah ada. Berdasarkan dua penelitian saya terdahulu, tema utama injil Matius ini adalah "Allah Bersama Kita," sementara "Retorika Pertarungan Kepemimpinan" merupakan hakikat retorikanya (Bdk. Surbakti, 2017, p. 29-74; Surbakti, April 2019, p. 2-7). Keduanya sesungguhnya saling berkaitan. Oleh karena hendak meyakinkan pembaca pada tema utama injil yang kemudian membuat retorika injil Matius ini menjadi sedemikian rupa. Selanjutnya keduanya akan digunakan sebagai bingkai kerja penafsiran yakni peta yang menuntun penafsir menemukan pesan dari teks.

\section{Apakah Porneia bisa berarti Zinah?}

Dalam bahasa Yunani, kalimat Yesus dalam Matius 19:9 berbunyi, "hos an apolusē tên gunaika autu mē epi porneia kai gamēsē allēn moichatai" Dalam terjemahan Lembaga Alkitab Indonesia Terjemahan Baru (LAI-TB) kata porneia dan moichao tersebut sama-sama diterjemahkan "berzinah". Kata moichao memang umumnya diterjemahkan berzinah (Bdk. Mat. 5:32; 19:9; Mark. 10:11, 12) yang dalam terjemahan bahasa Inggris diterjemahkan "commit adultery" (bdk. KJV, NIV, RSV). Namun apakah kata porneia dalam ayat ini juga dapat diterjemahkan dengan kata berzinah?

Kata porneia muncul 25 kali dalam Perjanjian Baru (PB). Dalam terjemahan LAI-TB, ada dua terjemahan untuk kata ini, yaitu zinah (4 kali) dan cabul (21 kali). Sedangkan kata porneia dalam Matius 19:9 dalam terjemahan bahasa Inggris juga diterjemahkan secara beragam, yaitu: fornication (KJV), immorality (NKJV), marital unfaithfulness (NIV), unchastity (RSV). Malina (1972, p. 17) menyimpulkan bahwa porneia lebih kepada perilaku seksual yang dilarang dalam Taurat. Namun Malina juga menambahkan bahwa hubungan seksual antara laki-laki dan perempuan (heteroseksual) sebelum pertunangan, sebelum pernikahan, serta yang bersifat nonkomersial dinilai bukanlah sebagai kejahatan moral dalam ketentuan Taurat (Malina, 1972, p. 17). Dengan demikian hubungan seks semacam itu bukanlah porneia. Tulisan ini kemudian direspons oleh Joseph Jensen dalam artikelnya, "Does Porneia Mean Fornication? A Critique of Bruce Malina." Penentangan keras terhadap kesimpulan Malina tersebut langsung disajikan di awal tulisan tersebut,

It is my contention that MALINA can be faulted at almost every stage of his argumentation (classification of some of the texts in question, conclusions from rabbinic sources, conclusions from the Old Testament, etc.), ... (Jensen, 1978, p. 162).

Ada beberapa argumentasi yang diajukan oleh Jensen, namun utamanya adalah berdasarkan sebuah realitas bahwa apa yang tidak dilarang dalam ketentuan Taurat tidak bisa diasumsikan juga pasti tidak dilarang dalam ajaran Yesus maupun Paulus, seba- 
liknya apa yang dilarang dalam Taurat, misalnya hal-hal yang menajiskan, justru tidak dilarang dalam kekristenan (Bdk. Jensen, 1978, p. 164). Dalam kelanjutan tulisannya tersebut Jensen kemudian melakukan evaluasi terhadap sumber-sumber literatur Yahudi (PL, Qumran, dan Literatur Rabinik) yang digunakan oleh Malina untuk mendukung kesimpulannya di atas. Dalam kesimpulannya, Jensen melihat makna kata porneia dalam PB memang beragam, namun dalam kaitannya dengan tujuan tulisan ini Jensen (1978, pp. 179-180) menyatakan, “... there is no basis for denying that the New Testament could use porneia to designate simple fornication." Artinya, porneia juga dapat merujuk kepada semua model hubungan seks di luar pernikahan, bahkan dengan dimensi yang lebih luas daripada moichao. Janzen yang secara khusus membahas makna kata porneia dalam Matius 5:32 dan 19:9 menyatakan,

..., the point of this article is to show that the cultural context of the evangelist leads one to expect a meaning for porneia of something like 'adultery'. If Matthew uses porneia instead of moicheia, it is likely because he or she wishes to indicate that it is not simply sex during marriage that constitutes a permissible reason for a man to divorce, but also sex during betrothal (Janzen, 2000, p. 69).

Dengan mengutip pandangan J. Laney (Laney, 1990, p. 34), Ajayi menilai bahwa bagi Yesus porneia dan moichao memiliki perbedaan arti (Ajayi, 2016, p. 8). Karena itu jugalah kedua kata ini muncul bersamaan dalam Matius 15:19. Namun demikian kedua kata ini memiliki irisan yang cukup lebar. Dalam artikelnya tersebut, Ajayi sepakat dengan banyak penafsir yang menyimpulkan bahwa keduanya memiliki kesamaan. Dalam masyarakat Yunani, kata ini umumnya dikaitkan dengan kegiatan prostitusi. Memang pada zamannya ada kegiatan prostitusi yang legal, namun kegiatan tersebut tetap memiliki konotasi negatif. Dalam kekristenan awal, kegiatan tersebut sangat ditentang (Bdk. 1 Kor. 5-6; Why. 2:20-22) dan dikaitkan dengan aktivitas seksual yang menyimpang. Dengan mengutip Instone-Brewer (2002, p. 156), tentang porneia, Ajayi (2016, p. 8) menyatakan, "It has a wider range of connota- tions throughout the area of sexual sin and impropriety, including the act of adultery." Gagasan ini memiliki kemiriban dengan Janzen yang juga menyatakan bahwa porneia memang merujuk kepada hubungan seks di luar pernikahan termasuk hubungan seks selama pertunangan (Janzen, 2000, p. 79).

Lebih jauh Harper (2011, p. 363-383) mencoba melakukan survei mendalam tentang pemaknaan kata porneia ini. Surveinya dimulai dari era Yunani klasik, Romawi, Helenisme, hingga PB. Sumbersumber surveinya terhadap kata ini juga sangat luas dan beragam. Dari survei itu tergambarkan bahwa pemaknaan terhadap kata ini, termasuk pada era PB sekalipun, memang sangat beragam (Harper, 2011, p. 375-379). Karena itu saya pun tidak akan mengusulkan sebuah makna tunggal. Namun yang pasti bahwa sejak awal porneia memang selalu dikaitkan dengan permasalahan seksual. Kepentingan dalam tulisan ini terutama bukanlah makna tunggal tersebut, namun lebih kepada kaitannya dengan moichao yang juga digunakan dalam Matius 5:27-28.

Jadi, walaupun para penafsir membedakan arti porneia dan moichao, namun hampir semuanya sepakat bahwa keduanya memiliki irisan yang sangat lebar. Secara semantik, porneia memiliki makna yang lebih luas daripada hanya sekadar adultery yang dimaknai sebagai hubungan seks di luar pernikahan (moichao). Dimensi penyimpangan seksual porneia lebih luas dari pada moichao. Dengan demikian, kata porneia dapat saja diterjemahkan berzinah, namun zinah yang dimaksud tentu saja lebih serius dari moichao. Beberapa penolakan terhadap terjemahan ini telah didiskusikan dengan cukup baik dan mendalam oleh Janzen (Janzen, 2000, p. 68). Selain commit adultery, porneia mencakup berbagai penyimpangan seksual yang tidak bermoral lainnya (TDNT VI, 1968, p. 579-595).

\section{Survei Terhadap Isu Perceraian dalam Matius 19:1-12}

Banyak penafsir yang membahas isu perceraian dalam Matius 19:1-12 ini menilai bahwa Yesus 
tengah terhisap ke dalam polemik antara dua kelompok utama dalam tubuh Yudaisme abad pertama (first century Judaism), yakni antara kelompok Hilel dan kelompok Shamai (Bdk. Hagner, 1995, p. 549; Barus, 2014, p. 5-6; Ajayi, 2016, p. 1, 3). Perdebatan tersebut direkam dalam Mishnah (Bdk. m Gitt. 9.10, http://www.sefaria.org/). Dalam menafsir kitab suci, kelompok Hilel dinilai sebagai kelompok yang lebih progresif daripada kelompok Shamai yang dinilai sebagai kelompok yang cenderung konservatif. Syarat perceraian bagi kelompok Hilel lebih longgar daripada bagi kelompok Shamai yang dinilai lebih ketat. Bagi kelompok Hilel, seorang suami bisa menceraikan istrinya dengan berbagai alasan, sementara bagi kelompok Shamai perceraian hanya dibenarkan dengan syarat tertentu. Dasar kedua kelompok tersebut sama-sama ada pada Ulangan 24:1 namun ditafsirkan secara berbeda. Perbedaan mengenai alasan perceraian inilah yang dinilai menjadi salah satu latar pertanyaan kelompok Farisi dalam Matius 19:3, "Apakah diperbolehkan orang menceraikan isterinya dengan alasan apa saja?" Motif pertanyaan itu sendiri disebutkan sebagai upaya untuk mencobai Yesus (Mat. 19:3). Kemudian perntanyaan yang dapat timbul adalah "Apakah dengan demikian Yesus sedang menentang kelompk Hilel dan mendukung kelompok Shamai?"

Zinah memang menjadi hal yang sangat dilarang dalam Taurat (Bdk. Ul. 20:13). Hukuman atas pelanggarannya bahkan bisa hukuman mati (Bdk. Im. 20:10; Ul. 22:22). Karena itu tidak heran bila kelompok Shamai membenarkan seorang suami menceraikan istrinya yang berzinah. Apakah Yesus sepenuhnya sependapat dengan gagasan ini? Sebagaimana yang telah disinggung di atas bahwa sebagian besar penafsir menyimpulkan bahwa melalui frasa pengecualian dalam Matius 19:9 tersebut, Yesus membenarkan seorang suami menceraikan istrinya yang berzinah. Dengan itu pula seorang suami Kristen dinilai boleh menceraikan istrinya yang berzinah. Menurut saya kesimpulan ini perlu mendapat perhatian yang lebih komprehensif.

\section{Perceraian dalam Yudaisme Abad Pertama}

Sebagai sebuah produk retorika, peredaksian melalui pengulangan isu perceraian hingga dua kali (Mat. 5:31-32 dan 19:1-12) dalam Injil ini bukan kebetulan. Hal ini mengindikasikan perceraian merupakan masalah yang sangat serius dalam pelayanan Yesus. Itulah mengapa pengajaran tentang hakikat pernikahan menjadi perhatian utama Yesus (Mat. 19: 4-6).

Pernikahan dalam tradisi orang Yahudi, dan dalam tradisi Timur pada umumnya, menuntut keterlibatan keluarga besar dari kedua mempelai. Sebelum pernikahan berlangsung, ada sejumlah kesepakatan keluarga yang harus dibicarakan dan disepakati, tidak saja oleh kedua mempelai namun juga oleh kedua keluarga besar. Dalam tradisi Yahudi, pihak laki-lakilah inisiator sebuah pernikahan. Ketika seorang laki-laki hendak melamar seorang perem-puan dan lamarannya diterima, maka pihak laki-laki harus menyerahkan sejumlah uang dan atau barang berharga kepada pihak perempuan. Karena nilainya biasanya cukup besar maka orang tua pihak laki-laki harus ikut mendukung. Tidak hanya kepada keluarga perempuan, sejumlah uang atau barang berharga lainnya juga biasanya diberikan kepada calon pengantin perempuan. Dengan demikian pernikahan membutuhkan persiapan dan biaya yang tidak sedikit. Kisah proses penjajakan pernikahan Ishak anak Abraham dan pernikahan Yakub anak Ishak sering diambil sebagai rujukan tentang hal ini.

Ketika Abraham menyuruh hambanya pergi ke kota Nahor untuk mencarikan istri bagi Ishak, Abraham menyertakan sepuluh ekor Unta dan berbagai barang berharga agar nantinya bisa diserahkan kepada keluarga calon pengantin perempuan dan calon pengantin itu sendiri (Bdk. Kej. 24:10). Apa yang dipersiapkan oleh Abraham ini merupakan bagian dari mahar dalam tardisi pernikahan pada era leluhur Israel (Hamilton, 1995, p. 144). Wenham (1994, p. 143) menyatakan, "Betrothal was marked by presenting large gifts to the bride's family,...". Pada bagian lain Wenham (1994, p. 149) menyatakan, "Betrothal was customarily effected in the 
ancient Near East by large capital transfers from the bridegroom's family to the bride's family." Karena itu setelah lamaran diterima, hamba Abraham itu menyerahkan barang berharga tersebut baik kepada Ribka (calon pengantin) maupun kepada pihak keluarga pengantin.

Kemudian hamba itu mengeluarkan perhiasan emas dan perak serta pakaian kebesaran, dan memberikan semua itu kepada Ribka; juga kepada saudaranya dan kepada ibunya diberikannya pemberian yang indah-indah (Kej. 24:53).

Kisah ini agak berbeda dengan kisah Yakub. Karena alasan tertentu, secara material pernikahan Yakub tidak didukung oleh ayahnya Ishak. Namun hal itu tidak membatalkan kewajiban untuk memberikan sejumlah uang dan atau barang berharga kepada keluarga calon pengantin perempuan dan calon pengantin perempuan itu sendiri. Walaupun Laban sangat menyayangi Yakub (Bdk. Kej. 29:13-14), dalam Kejadian 29:18-28 dikisahkan bahwa untuk mendapatkan satu orang anak gadis Laban, Yakub harus bekerja untuk Laban selama tujuh tahun. Upah selama tujuh tahun itu merupakan pengganti kewajiban penyerahan uang dan atau barang berharga tersebut. Ketika mengulas istilah bride money, atau ada yang menyebutnya bride-price (Hamilton, 1995, p. 144), Wenham (1994, p. 149) menyatakan bahwa nilainya setara dengan upah bekerja selama beberapa tahun. Lalu Wenham pun mengaitkan bride money ini dengan kisah Yakub yang bekerja untuk Laban ini, "It appears that the 'beautiful presents' given to Laban and his mother probably equivalent to the bride money." (Wenham, 1994, p. 149; Bdk. Hamilton, 1995, p. 144).

Dari kedua kisah di atas dapat dilihat bahwa pernikahan dalam tradisi bapa leluhur orang Yahudi merupakan peristiwa yang memiliki proses yang panjang dan melibatkan banyak pihak. Ia tidak mudah dan tidak murah, utamanya bagi pihak laki-laki. Perceraian memang dimungkinkan, namun selain membutuhkan proses, ia juga membutuhkan dana yang tidak sedikit. Setidaknya pada era Yudaisme abad pertama, ketika terjadi perceraian maka pihak suami umumnya diharuskan membayarkan mahar se- bagai bagian dari kontrak pernikahan Yahudi atau Ketubah [bdk. m. Mak. 1.1; m. 'Arak. 6.1-2 (bdk. Alexander, 2015, p. 23; http://instonebrewer.com/; Tuckett, 1983, p. 23)]. Hal tersebut bahkan juga berlaku bila terjadi saat masih bertunangan (Bdk. $\mathrm{m}$. Yev. 15.7; http://www.sefaria.org/Mishna_Yevamot. 15?lang=bi). Dalam tradisi Yahudi, perceraian tanpa pembayaran uang mahar merupakan pelanggaran yang sangat serius.

Pembayaran mahar dalam perceraian memang bisa saja tidak dilakukan, namun dengan syarat si istri didapati melakukan pelanggran, antara lain zinah. Dalam hal ini pihak suami harus mampu menghadirkan saksi-saksi yang dapat meyakinkan para pemimpin agama bahwa si istri memang benarbenar telah melakukan pelanggaran. Inilah antara lain yang membuat seorang suami akan berpikir keras ketika hendak menceraikan istrinya.

Entah karena rumitnya proses pembuktian atau besarnya mahar, ada saja peristiwa dimana suami mencoba menghindar dari ketentuan ini dengan merekayasa saksi dan proses kesaksian. Dalam $b$ Gittin 57a misalnya, dicatat kisah seorang suami yang hendak menceraikan istrinya dengan merekayasa peristiwa (http://www.come-and-hear.com/; Jansen, 2000, p. 75). Oleh karena tidak mau membayar mahar, seorang suami memanfaatkan seorang teman-temannya dengan memberinya makan dan minuman keras hingga mabuk. Dalam keadaan demikian ia lalu membaringkan teman-temannya tersebut di tempat tidur dimana istrinya juga tidur. Peristiwa itu pun dijadikan sebagai bukti perzinahan istrinya sehingga ia tidak perlu membayar mahar. Dalam kelanjutan kisahnya rekayasa atas kesakisan palsu tersebut terbukti, karenanya selain dipaksa membayar mahar, suami tersebut pun dihukum cambuk.

Dalam hal inilah, alasan perceraian yang ditanyakan oleh Farisi dalam Matius 19:3 ini menjadi menarik bagi para suami Yahudi. Ia bukan lagi sekadar persoalan penafsiran yang lebih progresif seperti kelompok Hilel atau lebih konservatif seperti Shamai, namun memuat dimensi kemunafikan.

Pada perkembangan selanjutnya, tradisi yang ketat dalam perkawinan di atas semakin long- 
gar. Interpretasi ketiadaan syarat atau syarat terbatas perceraian pun menjadi salah satu bentuk melonggarnya hukum tentang perceraian tersebut. Hal ini membuat keputusan suami menceraikan istrinya juga semakin mudah dan cepat. Pernikahan menjadi proses transaksional yang berkutat dalam gagasan untung-rugi. Itulah mengapa respons para murid ketika Yesus menjelaskan hakikat sebuah pernikahan adalah, "Jika demikian halnya hubungan antara suami dan isteri, lebih baik jangan kawin" (Mat. 19:10). Yesus sebelumnya mengatakan,

Jawab Yesus: "Tidakkah kamu baca, bahwa Ia yang menciptakan manusia sejak semula menjadikan mereka laki-laki dan perempuan? Dan firman-Nya: Sebab itu laki-laki akan meninggalkan ayah dan ibunya dan bersatu dengan isterinya, sehingga keduanya itu menjadi satu daging. Demikianlah mereka bukan lagi dua, melainkan satu. Karena itu, apa yang telah dipersatukan Allah, tidak boleh diceraikan manusia." (Mat. 19:4-6).

Konsekuensi dari kalimat di atas tentu saja larangan untuk suami menceraikan istrinya, sebagaimana yang dicatat dalam Matius 19:9 yang akhirnya melahirkan respons para murid dalam Matius 19:10 di atas. Dengan mengutip bagian dari Kejadian 2 di atas, Yesus menilai bahwa hakikat pernikahan adalah ketetapan Allah, bukan semata-mata keputusan manusia yang bersifat transaksional. Namun jangankan di kalangan orang Yahudi pada umumnya, para murid sendiri pun merasa asing dengan hakikat perkawinan tersebut. Karena itulah mereka berkata, "Jika demikian halnya hubungan antara suami dan isteri, lebih baik jangan kawin." (Mat. 19:10). Para murid sulit menerima hakikat perkawinan semacam itu. Mereka telah lama hidup dalam gelombang modernitas yang mana perceraian telah menjadi hal yang biasa, relatif mudah dan murah. Ia murah karena pembuktian pelanggaran, utamanya oleh istri, bisa direkayasa. Ia mudah karena interpretasi terhadap alasan perceraian pun memang mudah bahkan bisa tanpa alasan. Dalam Mishnah Gittin 9:10 yang telah disinggung di atas misalnya, menurut kelompok Hilel seorang suami Yahudi bahkan bisa menceraikan istrinya dengan alasan yang sangat sepele seperti masakan yang gosong. Masih dalam teks yang sama, Rabbi Akiba juga menilai bahkan bila seorang suami melihat perempuan lain yang lebih cantik dari istrinya, suami tersebut bisa saja menceraikan istrinya (http://www.sefaria.org/Mishnah _Gittin.9.10? lang=bi). Pernikahan dengan demikian bukan lagi ketetapan Allah, namun semata-mata adalah keputusan manusia. Inilah yang menjadi salah satu latar sosial dialog antara Yesus dengan orang-orang Farisi dalam teks ini.

\section{Apakah Yesus Membenarkan Suami Menceraikan Istrinya yang Berzinah?}

Jawaban Yesus atas pertanyaan orang-orang Farisi dalam teks ini jelas bertentangan dengan pandangan kelompok Hilel. Namun tidak berarti Ia sepenuhnya sependapat dengan kelompok Shamai yang membenarkan seorang suami menceraikan istrinya yang berzinah. Dalam jawaban-Nya, Yesus secara implisit tidak membenarkan seorang suami menceraikan istrinya yang berzinah. Hal ini akan tampak melalui dua bingkai kerja penafsiran di atas.

Sebagaimana yang telah disebutkan di atas bahwa hakikat retorika injil ini adalah sebuah retorika pertarungan kepemimpinan (Baca Surbakti, 2017, pp. 29-74; Surbakti, 2019, pp. 2-7). Ia merupakan pertarungan antara Yesus sebagai pemimpin baru orang Yahudi (Bdk. Mat. 2:6) dengan pemimpin Yahudi. Karena itu tidak mengherankan bila injil ini sarat dengan dialog yang bernada polemik antara Yesus dan para pemimpin Yahudi (Bdk. Surbakti, 2014, pp. 38-39). Topik dialog bernada polemik tersebut adalah seputar kepemimpinan yang mampu mewujudkan Allah yang dekat dan hadir dalam kehidupan manusia.

Perlu dipahami bahwa para penafsir memperkenalkan sejumlah kelompok dalam Yudaisme yang dengannya Yesus berpolemik menjadi satu karakter. Karakter inilah yang saya identifikasi sebagai pemimpin Yahudi dalam tulisan ini. Memang identifikasi terhadap pemimpin Yahudi cukup beragam, antara lain: Religious Leaders (Powell, 1988), Leaders of Israel (Camp, 2002, p. 10), Jerusalem lea- 
ders (Saldarini, 2003, p. 1045), the Jewish Leadership (Harlow, 2012, p. 412; Hannan, 2006, p. 187191), the Jewish Leaders (Gundry, 1994, p. 453). Namun demikian penjelasan Camp (2002, p. 10) dalam disertasinya terhadap berbagai identifikasi karakter di atas tampaknya cukup mewakili, "Leaders of Israel' will be preferred title for group encom-passing scribes, Pharisees, Sadducees, Herodians, lawyers, priests and elders."

Sebagai unit narasi retorika pertarungan kepemimpinan, Yesus tentu saja dikarakterisasi tidak sependapat dengan pemimpin Yahudi tersebut. Selanjutanya karakterisasi negatif dari para pemimpin Yahudi pun sering ditampilkan. Dalam teks ini ia ditampilkan melalui motifnya yang hendak mencobai Yesus (Mat. 19:3). Melalui realitas ini dapat disimpulkan bahwa Yesus tentu saja tidak sependapat dengan orang-orang Farisi tersebut. Baik perceraian tanpa syarat (Hilel) maupun perceraian dengan syarat (Shamai) sama-sama tidak dibenarkan oleh Yesus. Selanjutnya bila kita mengamati kalimat Yesus sebelum mengangkat isu ini pertama kalinya dalam Matius 5:31-32, semakin memperlihatkan bahwa Yesus tidak sepenuhnya sepakat dengan perceraian dengan syarat (Shamai). Hal ini tampak dari tindakan Yesus yang melakukan reinterpretasi terhadap pemahaman umum mengenai perceraian yang tentu saja lahir dari pengajaran para pemimpin Yahudi (ay. 32). Sejumlah reinterpretasi yang dilakukan oleh Yesus terhadap pemahaman yang selama ini diajarkan oleh para pemimpin Yahudi disajikan secara sistematis dalam Matius 5:21-48, dan isu perzinahan adalah salah satu di antaranya. Lagi pula dalam Matius 5:20 Yesus telah berkata kepada para muridNya, "Jika hidup keagamaanmu tidak lebih benar dari pada hidup keagamaan ahli-ahli Taurat dan orang-orang Farisi, sesungguhnya kamu tidak akan masuk ke dalam Kerajaan Sorga." Dengan ini semakin jelaslah ketidaksetujuan Yesus terhadap pendapat pemimpin Yahudi. Sebaliknya, Yesus justru meminta para murid agar memiliki standar kehidupan keagamaan yang melampaui standar kehidupan keagamaan para pemimpin tersebut.
Frasa hidup keagamaanmu adalah terjemahan dari humōn he dikaiosyne (kebenaranmu). Bila kita membaca respons murid dalam Matius 19:10 yang telah disinggung di atas, maka standar kehidupan keagamaan yang Yesus tuntut memang lebih tinggi dari yang dituntut oleh pemimpin Yahudi selama ini. Karena itulah para murid menyatakan, "Jika demikian halnya hubungan antara suami dan isteri, lebih baik jangan kawin" (Mat. 19:10). Bagaimana sesungguhnya kehidupan keagamaan para pemimpin Yahudi sehingga menjadi sorotan Yesus?

Sikap hidup pemimpin Yahudi yang paling disorot oleh Yesus adalah munafik. Kemunafikan tampaknya telah membudaya dalam praktik kehidupan sebagian besar pemimpin Yahudi pada era Yesus. Matius 23, yang sering dinilai sebagai klimaks plot retorika pertarungan ini (Bdk. Surbakti, 2014, p. 38; Surbakti, 2017, p. 79), menyorot secara tajam sikap yang munafik dari para pemimpin tersebut (Baca Surbakti, 2017, p. 83). Bagian ini memuat kecaman Yesus terhadap pemimpin Yahudi dengan mengawali sejumlah kalimat-Nya dengan "Celakalah kamu ..." secara berulang-ulang. Alasan sejumlah kecaman atas kemunafikan sebagian besar pemimpin Yahudi muncul di awal pasal 23 ini,

Ahli-ahli Taurat dan orang-orang Farisi telah menduduki kursi Musa. Sebab itu turutilah dan lakukanlah segala sesuatu yang mereka ajarkan kepadamu, tetapi janganlah kamu turuti perbuatan-perbuatan mereka, karena mereka mengajarkannya tetapi tidak melakukannya. (Mat. 23:2-3).

Kemunafikan pemimpin Yahudi adalah karena mereka mengajarkan hukum Tuhan tapi mereka sendiri tidak melakukannya. Mereka menuntut orang lain melakukan hukum Tuhan, tapi mereka sendiri tidak melakukannya. Inilah kemunafikan yang dimaksud oleh Yesus. Maraknya praktik kemunafikan ini akhirnya tidak saja berlaku pada tataran pemimpin, namun juga pada tataran rakyat atau umat. Ini pulalah yang menurut saya menjadi salah satu alasan pengulangan isu perceraian karena perzinahan dalam injil ini (Mat. 5:31-32 dan 19:1-12). 
Menarik sekali bahwa pada pengajaran yang pertama (Mat. 5:31-32), isu perceraian karena perzinahan ini diawali dengan redefinisi dari kata moichao (Mat. 5:27-28) yang sebelumnya telah disimpulkan memiliki irisan yang cukup lebar dengan kata porneia. Redefinisi ini merupakan bagian dari perwujudan tuntutan Yesus agar para murid memiliki standar kehidupan keagamaan yang melebihi kehidupan keagamaan para pemimpin Yahudi (Mat. 5: 20). Perzinahan (moichao) menurut Yesus tidak hanya ketika seseorang telah melakukan hubungan seks di luar pernikahan. Yesus berkata, "Tetapi Aku berkata kepadamu: Setiap orang yang memandang perempuan serta menginginkannya, sudah berzinah dengan dia di dalam hatinya" (Mat. 5:28). Bila pada isu perceraian, perzinahan perempuan menjadi sorotan, maka pada bagian redefinisi kata moichao ini justru perzinahan laki-lakilah yang menjadi sorotan.

Dengan redefinisi ini Yesus konsisten dengan apa yang Dia ucapkan sebelumnya ketika mengawali pengajaran-Nya terkait dengan isu perceraian ini yaitu Dia datang tidak untuk meniadakan Taurat, tetapi Yesus justru menggenapinya (Bdk. Mat. 5:17-19). Kata menggenapinya dapat dimaknai sebagai upaya untuk membuat hukum Musa tersebut dapat berfungsi sebagaimana mestinya, yaitu untuk menghadirkan keadilan dan belas kasihan dan kesetiaan (Bdk. Mat. 23:23). Kasih kepada Allah yang tidak menganulir kasih kepada sesama adalah inti dari Turat dan kitab para nabi (Bdk. Mat. 22:37-40). Itulah yang diteladankan oleh Yesus sebagai perwujudan Allah yang dekat dan hadir dalam kehidupan manusia.

Lebih jauh lagi, redefinisi tersebut sekaligus sedang merespons maraknya praktik kemunafikan. Terhadap sejumlah reinterpretasi yang dilakukan oleh Yesus dalam Matius 5:21-48 tersebut, Eduard Scweitzer (1975, p. 118) menyatakan, "In anthithesis and other sayings of Jesus it is made clear that there is no longer a sharp line between willing and acting." Melalui rinterpretasi tersebut Yesus sedang mempersempit jurang antara tindakan dan pikiran atau kehendak. Disintegrasi keduanya adalah bentuk kemunafikan.

Jadi dengan definisi yang baru dari kata berzinah dalam budaya androsentris di atas, apakah ada suami Yahudi yang benar-benar bebas dari perzinahan? Apakah ada suami yang tidak pernah memandang perempuan dan menginginkannya? Dengan definisi yang baru ini, boleh jadi hampir semua suami juga pernah, bahkan sering, melakukan zinah (moichao). Apalagi dalam konteks Matius 19 ini, ada kecenderungan suami yang telah menceraikan istrinya berencana menikah kembali dengan perempuan lain. Karena itu dalam bagian ini Yesus menyinggung ide menikah kembali tersebut (Bdk. Mat. 19:9). Bukankah hal ini mengindikasikan adanya sikap yang memandang perempuan lain dan menginginkannya pada saat belum bercerai? Jadi bila ada seorang suami yang pernah, bahkan sering, berzinah lalu menceraikan istrinya karena berzinah, tidakkah tepat dinilai sebagai sebuah praktik kemunafikan? Karena itulah melalui frasa kecuali karena zinah tersebut, secara implisit Yesus justru tidak sedang membenarkan perceraian karena perzinahan istri. Dengan ini Yesus sama sekali tidak sedang menganulir tuntutan hukum Musa terkait dengan istri yang berzinah. Perzinahan istri adalah kejahatan, tapi perzinahan suami juga adalah kejahatan.

Kalimat Yesus yang seolah-olah membenarkan suami yang hendak menceraikan istrinya karena perzinahan tersebut memiliki kesejajaran motif dengan kalimat Yesus dalam Yohanes 8:7, "Barangsiapa di antara kamu tidak berdosa, hendaklah ia yang pertama melemparkan batu kepada perempuan itu." Kalimat Yesus ini bermula dari kisah para Ahli Taurat dan orang-orang Farisi yang meminta pendapat Yesus atas seorang perempuan yang tertangkap telah berzinah (moicheo bukan porneia). Dalam kisah ini Yesus tidak sedang menentang hukum Musa yang memandang perzinahan sebagai kejahatan yang sangat serius. Secara implisit Yesus justru sedang mengajak para laki-laki untuk melihat dirinya terlebih dahulu sebelum melempari perempuan itu dengan batu. Dalam kelanjutan kisah ini, ternyata ti- 
dak ada laik-laki yang merasa layak melempari perempuan yang berzinah tersebut. Alasannya adalah karena mereka sadar bahwa tidak ada di antara mereka yang bebas dari dosa (Bdk. Sloyan, 1988, p. 97), bahkan dari dosa perzinahan (Bdk. Kanagaraj \& Kemp, 1973: 225). Sikap yang seperti inilah yang diharapkan Yesus berlaku dalam diri para suami yang hendak menceraikan istrinya karena istrinya dituduh telah berzinah. Harapan-Nya tentu saja agar perceraian tidak terjadi. Selain karena maraknya praktik yang manipulatif dalam perceraian, utamanya karena pernikahan pada hakikatnya adalah kehendak Allah sendiri.

Nuansa ketidaksetujuan Yesus terhadap suami yang hendak menceraikan istrinya karena berzinah ini secara implisit juga tampak dari penggunaan kata porneia bukan moicheo sebagai syarat seorang suami menceraikan istrinya. Seperti yang telah disimpulkan di atas bahwa walau moicheo dan porneia sama-sama bisa diterjemahkan sebagai perbuatan zinah, namun dimensi penyimpangan seksual dari kata porneia jauh lebih luas dari pada kata moicheo. Dengan kata lain suami yang hendak menceraikan istrinya harus benar-benar bisa membuktikan bahwa penyimpangan seksual yang berdimensi luas itu (porneia) telah dilakukan oleh istri, bukan sekadar moicheo. Dalam kelanjutan kalimat Yesus dalam Matius 19:9 ini, ditegaskan bahwa bila porneia tidak terpenuhi dan si suami ternyata menikah lagi maka ia telah melakukan zinah dengan istri barunya.

Selanjutnya dalam kaitannya dengan bingkai kerja kedua, retorika ini bermuara kepada hakikat Yesus sebagai wujud kehadiran Allah yang dekat dan hadir bersama umat. Gagasan ini merupakan antitesis dari pemimpin Yahudi yang gagal mewujudkan Allah yang dekat dengan manusia. Agama telah menjadikan Taurat menjadi kuk yang memberatkan (Bdk. Mat. 11:28-30). Melalui pemahaman semacam ini, manusia yang berdosa semakin jauh dari hadirat Allah. Karena itu, Yesus dalam injil Matius menyatakan bahwa diri-Nya hadir untuk memberi kelegaan bagi mereka yang letih lesu dan berbeban berat yaitu mereka yang terdiskriminasi dan terasingkan oleh
Taurat yang diajarkan oleh pemimpin Yahudi. Salah satu bentuk kegagalan para pemimpin dalam mewujudkan Allah yang dekat antara lain adalah dengan mengijinkan seorang suami menceraikan istrinya dengan alasan apa saja (kelompok Hilel) dan karena alasan perzinahan (kelompok Shamai) istri yang dilanjutkan dengan tindakan suami yang kawin dengan perempuan lain.

Bila bercermin pada praktik manipulatif di balik perceraian yang berpotensi melahirkan sikap yang munafik di atas (Bdk. b Gittin 57a) maka inti dari seluruh hukum Taurat dan kitab para Nabi tidak lagi tercapai. Dalam retorika ini, Yesus menyebutkan inti segala hukum ini sebanyak dua kali, yaitu dalam Matius 22:37-40 dan Matius 23:23. Kasih kepada Allah yang tidak menganulir kasih kepada sesama adalah inti dari hukum taurat dan kitab para nabi tersebut (Bdk. Surbakti, 2017: 153).

Bila ada suami yang menceraikan istrinya karena zinah sementara dirinya sendiri juga sering berzinah, hal itu justru bertentangan dengan inti hukum Taurat dan kitab para nabi. Bila dengan alasan mengasihi Allah yang membenci perzinahan, seorang suami lalu menceraikan istrinya dengan mudah apalagi manipulatif, hal itu telah menganulir kasih kepada sesama. Kalau kita bergerak lebih dalam pada realitas sosial orang Yahudi pada era Yesus yang telah disinggung di atas, bukankah praktik manipulatif juga marak terjadi di balik justifikasi perceraian? Karena ingin menghindari mahar dalam perceraian maka upaya merekayasa saksi bahwa si istri telah berzinah pun dilakukan. Atau karena suka kepada perempuan lain, lalu merekayasa saksi dalam proses perceraian, bukankah itu kemunafikan? Bila itu yang terjadi dan dibenarkan oleh para pemimpin Yahudi sebagai pihak yang memutus perkara perceraian tersebut, bukankah itu merupakan realitas mengasihi Allah dengan menganulir kasih kepada sesama yaitu istri yang diceraikan itu?

Selain itu ketika terjadi perceraian, termasuk karena perzinahan istri, maka situasi ini akan membuat istrinya menderita, apa lagi bila putusan itu dibuat dengan rekayasa. Terlepas dari apa alasan per- 
ceraian, perempuan yang diceraikan mendapat stigma negatif dalam masyarakat Palestina. Berdasarkan tarsirannya terhadap kisah perempuan dalam Yohanes 4:17, Keener (2003, p. 607) menyatakan, "There is little doubt that most ancient Mediteranean men would have assumed a large number of divorces to reflect badly on the woman herself, and to judge the situation in moral terms." Reputasi perempuan yang diceraikan ini antara lain yang juga membuat seorang imam Yahudi dilarang menikah dengan perempuan yang diceraikan (Bdk. Im. 21:7, 14; 22:13). Hal ini tampak dalam kalimat Wenham (1979, p. 291) berikut, "However innocent the divorced women was infact, her reputation was likely to have been afected by the divorce." Pada sisi lain, status janda mendapat perhatian besar dalam masyarakat Yahudi. Janda merupakan status sosial yang sangat lemah. Teks-teks yang memuat tuntutan untuk memerhatikan janda serta membela hak-hak mereka begitu melimpah dalam PL (Bdk. Kel. 22:21-23; Ul. 26:12; Ayb. 29:12-13; Yes. 1:17; Yer. 7:5-6). Karena itu bila hak-hak para janda, khususnya janda yang diceraikan, tidak diperhatikan maka potensi untuk hidup dalam perzinahan cukup besar. Untuk bisa bertahan hidup, mereka tentu saja harus bergantung kepada orang lain dalam hal ini termasuk laki-laki. Karena itulah kebutuhan akan kehadiran Allah yang dekat dengan manusia menjadi kebutuhan bagi seorang janda.

\section{DAFTAR RUJUKAN}

Ajayi, Dare E. (2016). Marriage from Biblical Tradition and Contemporary Contradictions: Jesus, The Jews, Moses, Paul and the Rest of Us. A Biblical exegesis of Matthew 19:3-9. https://www.academia.edu/13071201/Marriag e_from_Biblical_Tradition_and_Contemporar ע_Contradictions_Jesus_the_Jews_Moses_Pa ul and the Rest of Us (diakses 20 Juli 2019).

Alexander, P.S. (2015). "Rabbinic Biography and the Biography if Jesus: A Survey of the

\section{KESIMPULAN}

Setelah melalui penggunaan kedua bingkai kerja penafsiran di atas, terlihat bahwa dalam Matius 19:9 ini Yesus secara implisit tidak membenarkan seorang suami menceraikan istrinya yang berzinah. Pengajaran secara implisit ini menjadi penting untuk meneguhkan bahwa Yesus datang tidak untuk meniadakan Taurat tapi untuk menggenapinya (Bdk. Mat. 5:17-19) sekaligus sebagai strategi Yesus untuk terhindar dari jebakan orang-orang Farisi (Bdk. Mat. 19:3).

Karena maraknya praktik perceraian, termasuk karena alasan istri berzinah, membuat orang Yahudi pada era Yesus menilai bahwa tindakan itu sesuai dengan ketentuan Taurat. Padahal itu hanyalah sebuah interpretasi pemimpin Yahudi yang acap kali dikarakterisasi sebagai orang munafik. Karena itu menentang perceraian bisa saja dianggap juga menentang Taurat. Bila Yesus disimpulkan membenarkan perceraian tersebut maka ia bertentangan dengan hakikat retorika dan tema utama Injil ini. Kalau pun istri memang benar-benar terbukti melakukan zinah, apalagi bukan porneia tetapi hanyalah moicheo, pengampunan karena kasih selayaknya diberikan. Lagi pula, apakah ada suami yang tidak memiliki salah, sehingga mengapa membiarkan suami yang berdosa itu dibenarkan melempar istrinya dengan batu karena istrinya dinilai telah berdosa.

Evidence". Dalam Christopher M. Tuckett (Ed.), Synoptic Studies: The Ampleford Conferences of 1982-1983. London: Bloomsbury Academic Publising Plc.

Barus, Armand. (2014). "Bolehkah Bercerai?: Studi Matius 19:1-12," Jurnal Teologi Reformed Indonesia, Vol. 4, No. 1, p. 1-18.

Brewer, David Instone. (2002). Divorce \& Remarriage in the Bible. Grand Rapids, MI: Baker Books. 
Camp, Greg Alan. (2002). Woe to You, Hypocrites! Law and Leaders in the Gospel of Matthew. Disertasi Ph.D., Sheffield University.

Frederich Hauck dan Siegfried Schulz. (1968). porne, pornos, porneia dalam TDNT VI, 579595.

Gundry, Robert H. (1982). Matthew: A Commentary on His Literary and Theological Art. Grand Rapids: Eerdmans.

Hagner, Donald A. (1995). Matthew 14-28. WBC, Nashville: Thomas Nelson Publishers.

Hamilton, Victor P. 1995. The Book of Genesis: Chapters 18-50. NICOT, Grand Rapids: Eerdmans.

Hannan, Margaret. (2006). The Nature and Demands of the Sovereign Rule of God in the Gospel of Matthew. London: T \&T Clarck.

Harlow, Daniel C. (2012). "Early Judaism and Early Christianity". Dalam John J. Collins dan Daniel C. Harlow (Eds.), Early Judaism: A Comprehensive Overview. Grand Rapids: Eerdmans.

Harper, Kyle. (2011). "Porneia: The Making of a Christian Sexual Norm," JBL 131, no. 2, p. 363-383.

Hayes, John H and Carl R. Holladay. (2011). Pedoman Penafsiran Alkitab, Cet. 8. Jakarta: BPK GM.

Hidayat, Rofiq. (18 Juni 2018). Melihat Tren Perceraian dan Dominasi Penyebabnya. https://www.hukumonline.com/berita/baca/lt5 b1fb923cb04f/melihat-tren-perceraian-dandominasi-penyebabnya/ (Diakses 9 Juli 2019).

Janzen, David. (2000). "The Meaning of Porneia in Matthew 5:32 and 19:9: An Approach from the Study of Ancient Near Eastern," JSNT 80, p. 66-80.

Jensen, Joseph. Jan. (1978). "Does Porneia Mean Fornication? A Critique of Bruce Malina," NovT 20, p. 161-184.

Kanagaraj, Jey J. \& Kemp, Ian S. (1973). The Gospel According to John. Singapore: AsianTheological Association.
Keener, Craig S. (2003). The Gospel of John: A Commentary Vol. 1. Peabody-Massachusetts: Hendrickson Publishers.

Laney, J. (1990). Divorce and Remarriage, Four Christian View. Downers Grove, IL: IVP.

Malina, Bruce. (1972). "Does Porneia Mean Fornication?" NovT 14, p. 10-17.

Powell, Mark Allan. (1988). The Religious Leaders in Matthew's Gospel: A Literary-Critical Study. Disertasi Ph.D., Union Theological Seminary.

Saldarini, Anthony J. "Matthew". Dalam James D. Dunn (Ed.), Eerdmans Commentary on the Bible. Grand Rapids: Eerdmans.

Saputra, Andi. (03 April 2019). Hampir Setengah Juta Orang Bercerai di Indonesia Sepanjang $2018 . \quad$ https://news.detik.com/berita/d4495627/hampir-setengah-juta-orangbercerai-di-indonesia-sepanjang-2018 (Diakses 9 Juli 2019)

Schweizer, Eduard. (1975). The Good News According to Matthew, terj. David E. Green. Atlanta: John Knox Press.

Siburian, Bernhardt. (2019). "Analisis Faktor-Faktor Penyebab Perceraian Berdasarkan Keputusan Pengadilan Negeri Balige tahun 2017," JIREH: Jurnal Ilmiah Religiosity Entity Humanity, Vol. 1, No. 1 (Juni 2019), p. 31-39. https://www.ojsjireh.org/index.php/jireh/article/view/5

Sloyan, Gerard. (1988). John. Atlanta: John Knox Press.

Surbakti, Pelita Hati. (2014). "Kerajaan Allah: Antara Frasa yang Relevan dan Pemaknaan yang Relevan," Jurnal Teologi Reformed Indonesia Vol. 4, No. 1, p. 29-42.

(2017). Yang Terutama dalam Amanat Agung: Sebuah Pencarian Makna Kata Terein dalam Matius 28:20a. Jakarta: BPK GM.

(2019). "Menghidupkan Leluhur: Sebuah Penafsiran Terhadap Matius 22:32," Gema Teologika Vol. 4, No. 1, p. 1-16. (http://journal- 
theo.ukdw.ac.id/index.php/gemateologika/arti cle/view/414/279), Diakses 9 Juli 2019.

Talbert, Charles H. (2010). Matthew. Grand Rapids: Baker Academic.

Tuckett, Christopher M. (1983). Synoptic Studies: The Ampleforth Conferences of 1982 and 1983. London: Bloomsbury.

Vawter, Bruce. 1954. "The Divorce Clause of Mat. 5.32 and 19.9", $C B Q 16$, p. 155-167. (1977). "Divorce and the New Testament", $C B Q 39$, p. 528-542.

Wenham, David and Steve Walton. 2001. Exploring the New Testament, Volume I. London: SPCK.

Wenham, Gordon J. (1979). The Book of Leviticus. Grand Rapids: Eerdmans.
Wenham, Gordon. (1994). Genesis 16-50. WBC; Nashville: Thomas Nelson Publishers.

Wright, Christopher J.H. (2006). The Mission of God: Unlocking the Bible's Grand Narrative. Downers Grove: IVP.

http://instonebrewer.com/RabbinicTraditions/EngTe xt.php?StandardRef=San.11.6\&GotoRef=m.S an.11.6\&Words1UC $=\&$ Words $2 \mathrm{UC}=\& \&$ Word $\underline{\mathrm{s} 1 \mathrm{HA}}=\&$ Words $2 \mathrm{HA}=\&$ Resource $=\&$ Referenc $\mathrm{e}=$ ?Resource $=\mathrm{y} \cdot$ HebMTR $\&$ StandardRef $=$ Mak k.1.1; (Diakses 1 September 2019).

http://www.sefaria.org/Mishna_Yevamot.15?lang=bi , (diakses 10 Agustus 2019)

http://www.sefaria.org/Mishnah_Gittin.9.10?lang=bi (diakses 10 Agustus 2019). 